\title{
Mapping of the scientific production of industry 4.0 in the BRICS: reflections and interfaces
}

\author{
SUeli Menelau ${ }^{1}$ \\ Francisco GUilherme Lima MACEdo ${ }^{2}$ \\ PATRÍCIA LACERDA de CARVALHO ${ }^{3}$ \\ THIAGO GOMES NASCIMENTO ${ }^{4}$ \\ ANTÔNIO DEUSANY de CARVALHo JÚNIOR ${ }^{5}$
}

\author{
${ }^{1}$ Universidade Federal de Pernambuco (UfPe) / Núcleo de Gestão, Caruaru - PE, Brazil \\ ${ }^{2}$ Universidade de Brasília (UnB) / Programa de Pós-Graduação em AdMinistração (PPGA), Brasília - DF, BraZiL \\ ${ }^{3}$ Universidade Federal da Paraíba (UFPB) / Programa de Pós-Graduação em Administração, JoÃo Pessoa - PB, BraziL \\ ${ }^{4}$ Centro Universitário IESB / Mestrado Profissional em Gestão Estratégica de Organizações (MPGEO), Brasília - DF, Brazil \\ ${ }^{5}$ Universidade de SÃo PAUlo (USP) / InStituto de Matemática E Estatística, SÃo PAUlo - SP, BrazIL
}

\begin{abstract}
This article aims to analyze the recent scientific production about 4.0 Industry from BRICS countries (Brazil, Russia, India, China, and South Africa), published in leading academics journals. The 4.0 Industry incorporates nine technological innovations, which are related, directly and indirectly, to the evolution of Science and Technology (S\&T) in BRICS, diagnosed by the evolution of the financial support, the participation in S\&T in the Gross Domestic Product (GDP), and the number of researchers and publications, in each member country. The descriptive and exploratory research was built using bibliometrics. The population was made up of texts of the databases Scopus and Web of Science, and the final sample was composed of 51 interdisciplinary articles. The analysis considered indicators of characterization of scientific production, to a certain degree co-occurrence of scientific productivity and scientific collaboration of methodological features of the study. It is concluded that Chinese articles are predominant, and the research indicated the increase of studies about Industry 4.0 in S\&T in BRICS. There is still a need to effectively strengthen the cooperation of these countries in the aspects related to the subject, according to agreements already established in recent years. In addition, the academic production shows a vast field to be explored, with the need for cooperation and effective development of common S\&T objectives in BRICS.
\end{abstract}

Keywords: Fourth Industrial Revolution. Emerging Economy. Emerging Markets. Technological Innovation. Bibliometrics.

\section{Mapeamento da produção científica da Indústria 4.0 no contexto dos BRICS: reflexões e interfaces}

\section{Resumo}

Este artigo analisa o perfil atual da produção científica sobre a Indústria 4.0 do grupo de países emergentes formado por Brasil, Rússia, Índia, China e África do Sul (BRICS), constante nos periódicos de impacto. A Indústria 4.0 incorpora nove inovações tecnológicas que se relacionam, direta e indiretamente, com a evolução da Ciência e Tecnologia (C\&T) nos BRICS, constatada pelo crescente aporte financeiro, pela participação de C\&T no Produto Interno Bruto (PIB) e pela quantidade de pesquisadores e de publicações em cada país integrante. Esta pesquisa, descritiva e exploratória, foi construída por meio de bibliometria. A população foi constituída por textos das bases de dados SCOPUS e Web of Science e a amostra final foi composta por 51 artigos interdisciplinares. A análise considerou indicadores de caracterização da produção científica, de coocorrência de produtividade científica e de característica metodológica dos estudos. Conclui-se que a publicação de artigos apresenta predomínio chinês e a pesquisa indicou o incremento de estudos acerca da Indústria 4.0 em C\&T nos BRICS, havendo, ainda, a necessidade de fortalecimento efetivo da cooperação desses países nos aspectos vinculados ao tema, consoante a previsão de acordos e planos de trabalho já estabelecidos em anos recentes. Ademais, a fotografia da produção mostra um campo vasto a ser explorado, com a necessidade de cooperação e desenvolvimento efetivo de objetivos comuns voltados à C\&T nos BRICS.

Palavras-chave: Quarta Revolução Industrial. Economia emergente. Mercados emergentes. Inovação tecnológica. Bibliometria.

\section{Mapeo de la producción cientifica de la industria 4.0 en el contexto de los BRICS: reflexiones e interfaces Resumen}

El objetivo de este artículo es analizar el perfil actual de la producción científica sobre la industria 4.0 de los países Brasil, Rusia, India, China y Sudáfrica, constante en los periódicos de impacto. La industria 4.0 incorpora nueve innovaciones tecnológicas, que se relacionan directa e indirectamente con la evolución de la ciencia y la tecnología (C\&T) en los BRICS, constatada por el creciente aporte financiero, en la participación de C\&T en el Producto Interno Bruto (PIB), y en la cantidad de investigadores y de publicaciones en cada país integrante. La investigación, descriptiva y exploratoria, se construyó a través de una bibliometría. La población se compuso con textos de las bases de datos Scopus y Web of Science, y la muestra final, con 51 artículos interdisciplinarios. El análisis consideró indicadores de caracterización de la producción científica, de coexistencia de productividad científica y de característica metodológica de los estudios. Se concluye que la publicación de artículos presenta un predominio chino, y la investigación indicó el incremento de estudios acerca de la industria 4.0 en C\&T en los BRICS, y aún la necesidad de un fortalecimiento efectivo de la cooperación de estos países en los aspectos vinculados al tema, según la previsión de los acuerdos y planes de trabajo ya establecidos en años recientes. Además, la fotografía de la producción realizada muestra un campo vasto a explorar, con la necesidad de cooperación y desarrollo efectivo de objetivos comunes enfocados en C\&T en los BRICS.

Palabras clave: Cuarta Revolución Industrial. Economía emergente. Mercados emergentes. Innovación tecnológica. Bibliometría. 


\section{INTRODUCTION}

Currently, the factual assumptions of the growing and articulated integration of communication, technology and production processes in innovations encompassing cyber-physical systems, combined with global networks and digital platforms, are the enhancement of personalized mass production, the redefinition of value chains and increasing returns to scale (TADEU and SANTOS, 2016). This set of phenomena, which is still incipient, originated from the absorption of innovative technologies, radical when compared to the incrementalism of immediately preceding innovations, and the breadth of their occurrence in different scientific fields, is known as Industry 4.0 (RÜSSMANN, LORENZ, GERBERT et al., 2015; TADEU and SANTOS, 2016).

The role of industrial policies and business decisions to be made, focused on Industry 4.0 Technological Innovations (TIs), are critical success factors and should focus on 8 priority areas: a) standardization, and open standards, for an operational architecture of factory reference; b) management of complex systems; c) provision of a comprehensive broadband infrastructure for the industry; d) cyber security and Information Technology (IT) security; e) new organization and work design focused on the digital industrial age; $f$ ) training and continuing professional development; $g$ ) regulations and $h$ ) resource efficiency (KAGERMANN, WAHLSTER and HELBI, 2013).

It is noted that in Europe, in the United States of America (USA) and in Asia, the race to embrace Industry 4.0 technological innovations is already underway among companies (RÜSSMANN, LORENZ, GERBERT et al., 2015). However, for the organization of the countries on other continents, adopting these innovations can pose unique challenges. More than ever, due to the intensifying dispersion and integration effects of globalization, the economic and social progress of emerging economy countries are connected to the organization's competence to integrate IT processes as new management paradigms (COSTIN and WOOD-JÚNIOR, 1994; GOMES and STRACHMAN, 2005; KON, 2015).

Emerging economy countries, such as Brazil, are defined as having "relatively high levels of economic potential and international engagement, broader than traditional" (THE WORLD BANK, 2011, p. xvii). The general and simplified opinion is that the group of emerging countries formed by Brazil, Russia, India, China and South Africa (BRICS) is constituted by nations of the same category of analysis because they have an increasing influence on the interdependence of the world's countries in the financial, productive, commercial and technological spheres, playing a prominent role in the evolution of the world economy (THE WORLD BANK, 2011; LUÍS, 2016).

Two other characteristics common to the BRICS are a) their economic, political and social structures are dependent on existing technical-scientific know-how in market economies (such as technological advances); and b) their problems are caused by the lack of self-sustaining structures (GUERRA and FANTINELLI, 2001). For some authors (ABRAMOVITZ, 1986; PITASSI, 2014; SARTI and HIRATUKA, 2017), the growth of technologically backward countries is well beyond just overcoming the technological gap.

Therefore, IT catch-up industrial policies (GOMES and STRACHMAN, 2005; IPIRANGA, QUEIROZ, FROTA et al., 2012; COSTA, MENEZES and FRANZONI, 2016), capacity building for innovation (KAGERMANN, WAHLSTER and HELBI, 2013) and value appropriation (BRETTEL, FRIEDERICHSEN, KELLER et al., 2014; ROBLEK, MESKO and KRAPEZ, 2016) are, among others, promoters of technological infrastructure restructuring, of the increase (or decline) in economic and social performance, and of market growth and increased profitability of their organizations.

Given this scenario, understanding the impact that Industry 4.0 has had on the BRICS becomes a relevant argument. It is known that the starting point to demonstrate the overcoming of the limits that are imposed on a country's predisposition to growth is to analyze their technological capability proxies (patents) and their scientific capability proxies (academic articles), although it is recognized that both are limited measures (BERNARDES, RUIZ, RIBEIRO et al., 2006). Even so, the logic of the scientific production of a given field, or theme, is an important portrayal of a country's public policies interaction with the many actors that compose the social fabric (SILVA, HAYASHI and HAYASHI, 2011; MARICATO and NORONHA, 2012) and help unveil what scientific communities have devised and performed in their researches (HOFFMAN and HOLBROOK, 1993).

The first mention of the term Industry 4.0 was made in 2011 by the German government (see KAGERMANN, WAHLSTER and HELBI, 2013), whose original German version dates back to 2011 as a political-strategic proposal for the country's Research 
and Development (R\&D) (HERMANN, PENTEK and OTTO, 2016; QIN, LIU and GROSVENOR, 2016; ROBLEK, MESKO and KRAPEZ, 2016). And, although this phenomenon is in progress and not being analyzed ex post facto (DRATH and HORCH, 2014), in a search conducted in the SCOPUS and Web of Science databases, it was found, like Hermann, Pentek and Otto (2016), that the production of studies that analyze it theoretically is growing, but not those applied to the reality of the BRICS.

In this sense, few texts that developed elucidative theoretical framework about Industry 4.0, contextualized with the reality of the BRICS, were found, although Satyro, Sacomano, Silva et al. (2017) included Brazil, and Liao, Loures, Deschamps et al. (2017) covered China and India. Moreover, the need to study Industry 4.0 in different countries in similar geopolitical contexts has already been pointed out by Roblek, Mesko and Krapez (2016). With this gap in view, the scope of this research aimed to increase knowledge about the Industry 4.0 field in emerging economies, from the analysis of its theoretical basis.

This article analyzes the current profile of the scientific production on the BRICS Industry 4.0 in journals of impact, in order to contribute to the construction of thematic indicators. The text is organized, not counting this introduction, in five parts. Following, are some theoretical notes on Industry 4.0 and the association of Science, Technology and Innovation (ST\&I) with the BRICS. The third section describes the methodological procedures used in the research. The fourth section organizes, analyzes and discusses the main results reached, based on the descriptive and evaluative indicators that were used as the analysis lens. And the last section brings the conclusion, which point to the limitations and perspectives for future studies.

\section{Notes on Industry 4.0}

The Industrial Revolutions (IRs) have defined transitional periods of human life as much as the domestication on animals and plants has marked it (HUBERMAN, 2008; KON, 2015). The first IR (which happened between 1760 and 1840), marked by the invention of the steam engine, provided the mechanical production; the second began in the late nineteenth century, underpinned the advent of electricity and enabled mass production, particularly through assembly lines (SCHWAB, 2016; SCHWAB and DAVIS, 2018). The digital or computer cycle (third IR), which started in the early 1960s, was driven by the development of semiconductors, personal computing and the internet (SCHWAB and DAVIS, 2018).

Industry 4.0 follows the third IR - machines still needed specific professionals to notify and correct its errors and even to turn them on - and it is also called fourth IR (KAGERMANN, WAHLSTER and HELBI, 2013; DRATH and HORCH, 2014; SCHWAB, 2016). The main differentiating element between these last two revolutions is less based on the available digital tools (since in both cases it is possible to perceive them, albeit in significantly different evolutionary stages) and more, in a central way, on the different interactions between the technological categories covered by Industry 4.0 (SCHWAB and DAVIS, 2018).

They maintain, to some extent, the same previous patterns of transitions and events (CASTELLS, 2002; HUBERMAN, 2008), although the logic of pushing production has gradually been replaced by the need to pull production (KON, 2015), coupled with the demand of having a more elaborate measurement of inputs and outputs to establish the standards of this production (SCHWAB, 2016). Since then, the relevance of innovation has been broadened as a generator of instruments that boost the competitiveness of organizations, in private sector cases, and/or that promote success in obtaining value in the provision of services, in public sector cases. All this puts Industry 4.0 as a determinant of a fourth IR, which comes to further accelerate the process that goes from raw material to consumer, affecting all sectors of the industry.

It is said that in Industry 4.0 the owners of factories and commercial operations only want workers to program the machines that, in turn, will dominate the productive process and later lead to the dismissal of these employees, leaving only the boss to enjoy what the machines and their systems can offer (DRATH and HORCH, 2014). However, this issue goes beyond the mere diversification or specialization of the division of labor incorporated into the production process. What has been observed is that the effects of the creation of added value to products, resulting from innovations, negatively and positively impact the demand for jobs, generating new professional profiles (ROBLEK, MESKO and KRAPEZ, 2016) and requiring the workforce to migrate to new sectors and new activities that correspond to current market needs (KON, 2015). 
Industry 4.0 incorporates 9 ITs that are the foundations for the transformation of industrial production: a) automated robots; b) simulation; c) horizontal and vertical system integration; d) industrial Internet of Things (IoT); e) cyber security; f) cloud; g) additive manufacturing; h) augmented reality; and i) Big Data and Analytics (RÜSSMANN, LORENZ, GERBERT et al., 2015). These innovations can also be summarized and categorized as 3 megatrends: a) physics (autonomous vehicles, 3D printing, advanced robotics and new materials); b) digital (loT, blockchain and digital platforms); and c) biological (sequencing, activation and genetic editing, synthetic biology and 3D bioprinting) (SCHWAB, 2016).

Due to the dynamics resulting from these innovations, new modes of conducting the organization (resulting in organizational innovations), service restructuring and other opportunities emerged (KON, 2015). Nanotechnology has made hardware cheaper, therefore it has become feasible to add sensors to all places in an organization and to all products (MIYAZAKI and ISLAM, 2007). Industries now interconnect their devices through IoT. Internet communication (which involves dialogue not only between people $[\mathrm{C} 2 \mathrm{C}]$, but also between people and machines [C2M] and between machines [M2M]) becomes a trend in professional and social environments known as knowledge management 4.0 (DOMINICI, ROBLEK; ABBATE et al., 2016).

Knowledge management 4.0, in turn, has as its assumptions: a) high interactivity provided by cloud-saved databases (storing and processing data on computers across the planet without a defined location, but with the capacity of being turned on as more machines are needed to complete a task transparently to their uses); and b) powered by machines and consumers, contents made available in real-time and information and network collaboration mediated by technologies (ROBLEK, MESKO and KRAPEZ, 2016).

Thus, it gradually allows the production paradigm to move from a centralized and controlled to a decentralized and flexible production logic (HERMANN, PENTEK and OTTO, 2016). With these advances also came new problems and new solutions, because simply connecting a device to the network is not enough by itself (PALATTELLA, DOHLER, GRIECO et al., 2016). One of them, the excess of data to be processed, led to the emergence of cloud computing (JADEJA and MODI, 2012). From mass data analysis it becomes possible to reduce its quantity through machine learning (which enables pattern recognition in order to predict new events). This increase in the amount of data analyzed gave rise to the Big Data field (defined by the volume, variety, velocity, veracity, value, validity and verification of the data) (YIN and KAYNAK, 2015).

In this context, the main channels of knowledge flow permeate the interaction between university, company and State in the development of innovations coming from their R\&D, which, in turn, should be oriented towards investment protection, stability, data privacy and cybersecurity (KAGERMANN, WAHLSTER and HELBI, 2013; DRATH and HORCH, 2014). For Stock and Selinger (2016), this progress will only be sustainable if the opportunities are understood from a perspective that encompasses the macro (business model and value creation networks) and micro (equipment, human resources, decentralization, processes and products) dynamics of innovation management, simultaneously, by the actors involved.

\section{Notes on the BRICS}

The BRICS group has become synonymous with a change in the power axis in the 21st century, being considered as an indicator of the economic growth of a set of emerging markets, located outside the West and with relevant scope (MANSFIELD, 2014; KINGAH and QUILICONI, 2015; COOPER, 2016). Currently, the BRICS lead the development of ST\&I among developing countries, becoming a globally important force on the area (RÜSSMANN, LORENZ, GERBERT et al., 2015; DOMINICI, ROBLEK, ABBATE et al., 2016). In 2017, worldwide, BRICS shared $17 \%$ of R\&D, $28 \%$ of exports of high technology products and $27 \%$ between Science and Technology (S\&T) journals and articles (ZHAO, WANG, XIAO et al., 2018).

In 15 years, from 2002 to 2017, there was an evolution in the share of Gross Domestic Expenditure on R\&D (GDERD), measured in billions of US dollars (\$) and with Purchasing Power Parity (PPP $)^{1}$, at different stages of investment in R\&D in the BRICS. Graph 1 shows this evolution.

\footnotetext{
Establishes an alternative exchange rate method for comparing Gross Domestic Products (GDPs), considering local differences in the parameters.
} 


\section{Graph 1}

\section{GDERD (in \$ billions, PPP) - BRICS, USA e EU282}

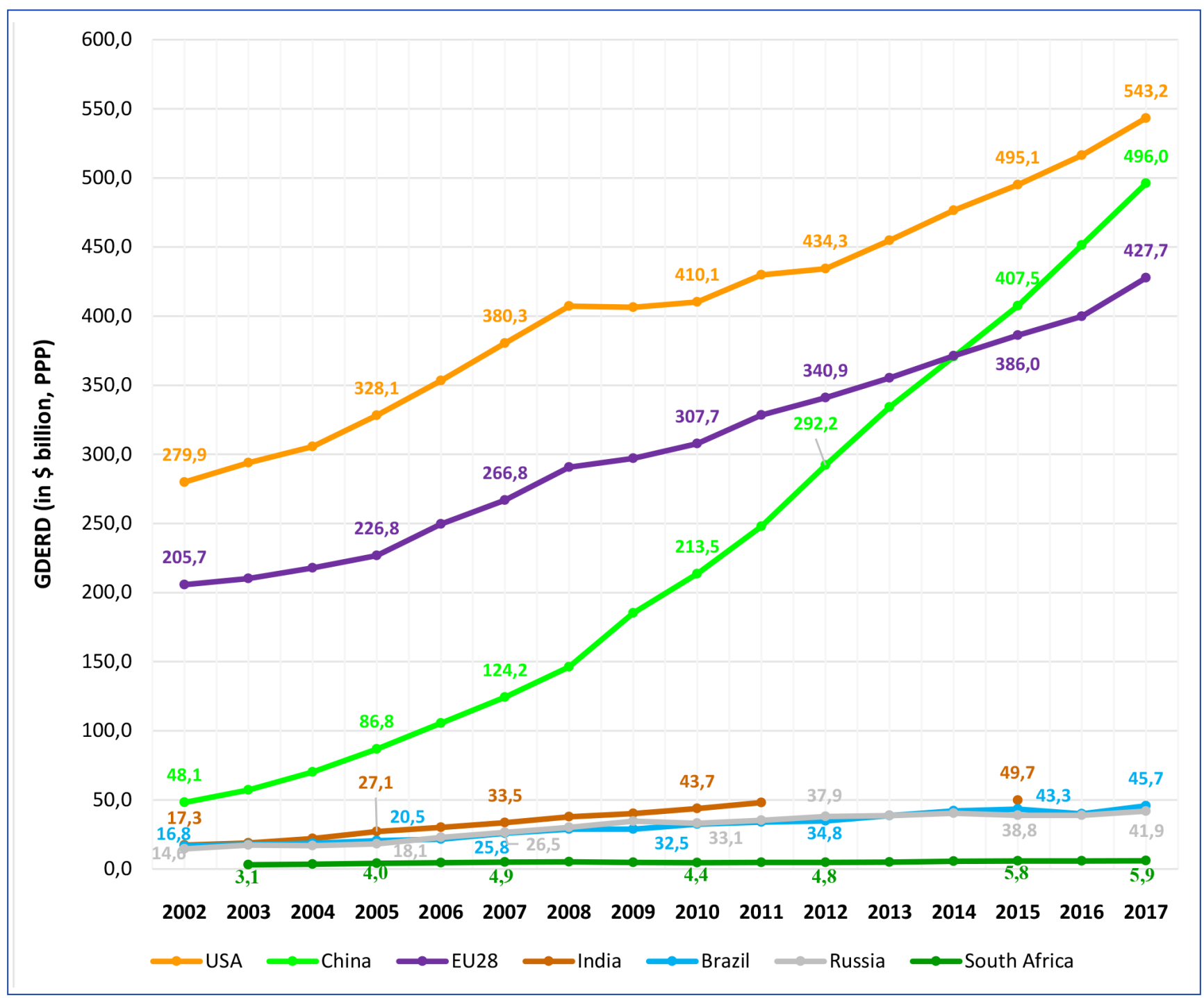

Source: Elaborated by the authors.

Graph 1 shows that in 2002 China presented a GDERD amount comparable to the sum of India, Brazil and Russia (\$ 48.1 versus $\$ 48.6$ billion) and just under $25 \%$ of the European Union investments with its 28 countries (EU28). In the year 2017, China surpassed EU28 GDERD by 16\%, only behind the USA, which demonstrates the reach of the scientific superpower stage (WONG and WANG, 2015; ZHAO, WANG, XIAO et al., 2018; OECD, 2019).

As for the other countries of the bloc: in Brazil, there was an increase of $272.9 \%$ between 2002 and 2017 , and \$ 45.7 billion of GDERD in 2017 (linear trend obtained over the previous decade); in Russia, an increase of $287.59 \%$ and \$ 41.9 billion in 2017 (between 2002 and 2017); and in India, an increase of 287.42\% (period from 2002 to 2015) and \$ 49.7 billion in 2015 (UNESCO, 2018a; OECD, 2019) ${ }^{3}$. It is noteworthy that the percentage increase in GDERD of the 3 countries is higher than the percentage increases of the USA and EU28 (194.09\% and 207.92\%, respectively), indicating an active trend in S\&T in the BRICS.

\footnotetext{
${ }^{2}$ The European Union Bloc consists of 28 countries- Austria, Belgium, Bulgaria, Croatia, Cyprus, Czech Republic, Denmark, Estonia, Finland, France, Germany, Greece, Hungary, Ireland, Italy, Latvia, Lithuania, Luxembourg, Malta, Netherlands, Poland, Portugal, Romania, Slovak Republic, Slovenia, Spain, Sweden and the United Kingdom. The most complete parameter established by the 28 countries in the bloc (UE28) was used in the verified comparison, although in other studies it is common to use the UE15 level, which relates to the 15 countries that first joined the bloc.

${ }^{3}$ Last year with country's consolidated data (UNESCO, 2018a).
} 
South Africa, however, even with its GDERD evolution from 2003 to 2015 (increase of 194.63\%)", spent only \$ 5.9 billion on this expenditure in 2015 (OECD, 2019).

When investment in GDERD is verified as a GDP percentage, the BRICS results (Graph 2) are less expressive than those of the previous scenario (Graph 1). The observation, again, is not valid for China, since besides being ahead in terms of the GDERD as a percentage of GDP, it displays another relevant data: in 2002, China represented the second largest GDERD percentage investment in the BRICS (1.06\% of the GDP), lower than Russia's investment (1.16\%), who was the leader in the bloc, but in 2017 China achieved $2.13 \%$ of GDP investment (OECD, 2019).

Brazil, like China, exhibited an increase in the percentage of GDERD in GDP in the period from 2002 to 2017 (0.98\% to 1.32\%, an increase of $0.34 \%)$, with variation greater than the growths of the US $(0.23 \%)$ and Europe $(0.27 \%)$ in the same period. However, the remaining BRICS countries declined (Russia, from 2002 to 2017, went from 1.16\% to 1.11\%; and in India there was a decrease from $0.74 \%$ to $0.62 \%$, during the period of 2002 to $2015^{5}$ ) or stagnated in this regard (South Africa, between 2003 and 2017, ranged from 0.76\% to 0.74\%) (UNESCO, 2018a; OECD, 2019). Graph 2 presents this scenario.

\section{Graph 2}

\section{GDERD (in \% of GDP) - BRICS, USA and EU28}

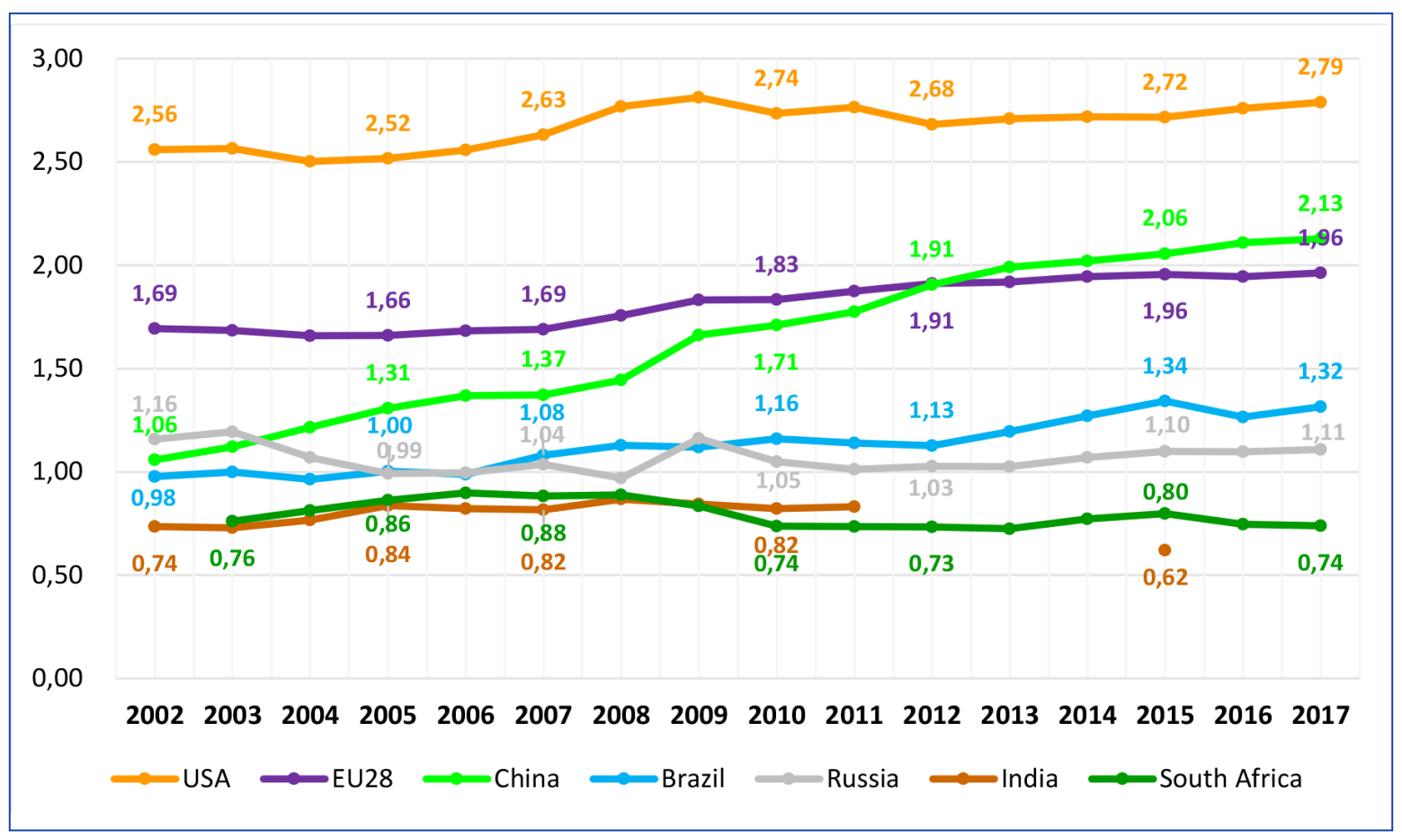

Source: Elaborated by the authors.

An information that adds to the understanding of this context is the direct implication between the investment contributions and the number of full-time researchers in the countries. In this regard, China is the world leader with more than 1.74 million employed researchers with full time dedication in 2017, and the country alone holds almost $90 \%$ of researchers from the EU28 (OECD, 2019). For the remaining countries of the BRICS, Russia ranks fourth (410.6 thousand researchers, in 2017); India ranks eighth (282.9 thousand in 2015); Brazil ranks tenth (179.9 thousand in 2014); and South Africa deviates from the others with 26.1 thousand researchers (UNESCO, 2018b; OECD, 2019).

Thus, both the increase in R\&D investments, either due to the values or the impact on GDP, as well as the repercussions of this budget employment, among which stood out the contribution of researchers in each country, influence in the advancement

\footnotetext{
${ }^{4}$ Information for 2003, 2016 and 2017 from South Africa is not available (OECD, 2019).

${ }^{5}$ Data from India only reached 2015 (UNESCO, 2018a) and South Africa's historical series start in 2003 (OECD, 2019).
} 
of the BRICS worldwide participation in the number of researches (29\% of publications indexed by SCOPUS in 2015) in prominent positions, considering the indexes in the referred base students between 2011 and 2015 in the global number of researches: China $\left(2^{\text {nd }}\right)$, India $\left(5^{\text {th }}\right)$, Brazil $\left(13^{\text {th }}\right)$, Russia $\left(14^{\text {th }}\right)$ and South Africa $\left(34^{\text {th }}\right)$ (FINARDI and BURATTI, 2016; SODOLOV, SHASHNOV, KOTSEMIR et al., 2018).

\section{METHODOLOGICAL PROCEDURE}

The research approach is quantitative, cross-sectional and its purpose is to describe and explore the field of Industry 4.0 in the BRICS (SANTOS and KOBASHI, 2009; SILVERMAN, 2009). The theoretical-methodological basis adopted consisted of a metric study focused on documentation, evaluation and orientation of the scientific production of the field (MARICATO and NORONHA, 2012; ROEMER and BORCHARDT, 2015). The approach leaned on quantifiable aspects that underlie the development of the literature on the theme and that can be segmented in categories; it has been found that all levels of complexity are required to understand the progress and multiplicity of a discipline (HOFFMAN and HOLBROOK, 1993). The article was based on a bibliometric, descriptive and evaluative analysis and the steps followed were: a) definition of the purpose of the analysis; b) identification, location and access to the sources of information; c) establishment of information search strategies for data collection; d) assignment of relationships between the data obtained; and e) elaboration of analysis categories and construction of descriptive and evaluative indicators (SILVA, HAYASHI and HAYASHI, 2011).

The data collection was performed in May 2018. Seeking to cover as many articles as possible, no temporal limit was established and texts in the SCOPUS and Web of Science databases were determined as the target population. These bases were selected because they are complementary, multidisciplinary and pointed as the most complete in terms of quantity and quality of the scientific publication covered (MONGEON and PAUL-HUS, 2016). In the portal's search tool, the fields summary, keywords and titles were accessed and for the article selection the criteria used were 2 sets of descriptors (searched in English): a) industry 4.0; e b) fourth industrial revolution and 4th industrial revolution (in written and numerical form), combined with the set of expressions (using the conjunction "and"): i) emerging countries; ii) emerging economies; iii) emerging nations; iv) emerging markets; v) BRICS; vi) Brazil; vii) Russia; viii) India; ix) China; and x) South Africa.

Only theoretical and empirical articles composed the research universe. Initially, 89 texts were recovered; after reading the abstracts, 34 duplicates and 4 articles with restricted access were excluded from the analysis. Then, after reading the complete article, 6 were discarded for either lacking adherence to the theme or object and 15 were written in languages other than English, Portuguese, French or Spanish ( 8 in Russian and 7 in Chinese). The non-probabilistic and intentional sample analyzed, due to the authors' intervention through the adopted criteria, resulted in 30 articles scrutinized according to 8 indicators grouped into 2 main categories:

1. Descriptive, elaborated based on Maricato and Noronha (2012): a) characterization of scientific production title and authorship of the text, year of publication of the article, distribution of articles by journal, theme(s) of the journal; b) co-occurrence - keywords; c) scientific productivity - author affiliation, number of articles (by institution and country); d) scientific collaboration - co-authorship; and e) methodological characteristic of the study - research typology;

2. Evaluative: f) employed concept of Industry 4.0 (defined concept and its authorship); g) formed conceptual subcategories (relations between ITs); and h) interfaces with the catch-up strategies phenomena, accumulation of capacities for innovation and appropriation of market opportunities.

The analysis, for all texts, included the reading of the complete document, and employed descriptive and content statistics. The latter covered the steps described above and added the following: a) revision of the categorization structure; b) reliability test of the categories; c) creation of an analytical file in Microsoft Excel spreadsheet for preliminary analysis (SILVERMAN, 2009). 


\section{RESULTS AND ANALYSIS}

\section{Descriptive Category}

The revised sample consisted of 30 articles (about 34\% of the initial collection), whose authors and titles are presented in Box 1.

\section{Box 1}

Texts analyzed (year of publication, title and authorship)

\begin{tabular}{|c|c|}
\hline \multicolumn{2}{|l|}{ PUBLISHED IN 2015} \\
\hline $\begin{array}{l}\text { Analysis of implementation of an automated process in a footwear company: a case study by } \\
\text { the optic of the Hyundai production system and Industry 4.0. }\end{array}$ & $\begin{array}{l}\text { Schröder, Nunes, } \\
\quad \text { Viero et al. }\end{array}$ \\
\hline \multicolumn{2}{|l|}{ PUBLISHED IN 2016} \\
\hline $\begin{array}{l}\text { A review of technology standards and patent portfolios for enabling cyber-physical systems in } \\
\text { advanced manufacturing. }\end{array}$ & $\begin{array}{l}\text { Trappey, Trappey, } \\
\text { Govindarajan et al. }\end{array}$ \\
\hline Atomic and close-to-atomic scale manufacturing - a trend in manufacturing development. & Fang \\
\hline From cyber-physical systems to Industry 4.0: make future manufacturing become possible. & Zhou, Liu and Liang \\
\hline Large-scale online multitask learning and decision making for flexible manufacturing. & Wang, Sun, Zhang et al. \\
\hline Industrial engineering curriculum in Industry 4.0 in a South African context. & Sackey and Bester \\
\hline \multicolumn{2}{|l|}{ PUBLISHED IN 2017} \\
\hline A conceptual framework for 'Industry 3.5' to empower intelligent manufacturing and case studies. & Chien, Hong and Guo \\
\hline $\begin{array}{l}\text { A cross-strait comparison of innovation policy under Industry } 4.0 \text { and sustainability development } \\
\text { transition. }\end{array}$ & Lin, Shyu and Ding \\
\hline $\begin{array}{l}\text { A digital twin-based approach for designing and multi-objective optimization of hollow glass } \\
\text { production line. }\end{array}$ & Zhang, Liu, Chen et al. \\
\hline $\begin{array}{l}\text { A review of essential standards and patent landscapes for the Internet of Things: a key enabler } \\
\text { for Industry 4.0. }\end{array}$ & $\begin{array}{l}\text { Trappey, Trappey, } \\
\text { Govindarajan et al. }\end{array}$ \\
\hline Additive manufacturing scenarios for distributed production of spare parts. & Durão, Christ, Zancul et al. \\
\hline An empirical study for smart production for TFT-LCD to empower Industry 3.5. & Chien, Hong and Guo \\
\hline Digital twin shop-floor: a new shop-floor paradigm towards smart manufacturing. & Tao and Zhang \\
\hline $\begin{array}{l}\text { Globalization and digitalization as challenges for a professional career in manufacturing industries- } \\
\text { differences in awareness and knowledge of students from Brazil and Germany. }\end{array}$ & Oliveira and Sommer \\
\hline Implementation of Industry 4.0 and lean production in Brazilian manufacturing companies. & Tortorella and Fettermann \\
\hline $\begin{array}{l}\text { Industry } 4.0 \text { learning factory didactic design parameters for industrial engineering education } \\
\text { in South Africa. }\end{array}$ & Sackey, Bester and Adams \\
\hline Integrated and intelligent manufacturing: perspectives and enablers. & Chen \\
\hline Intelligent manufacturing in the context of Industry 4.0: a review. & Zhong, Xu, Klotz et al. \\
\hline New IT driven service-oriented smart manufacturing: framework and characteristics. & Tao and Qi \\
\hline Advanced Manufacturing: What Is to Be Learnt from Germany, the U. S., and China. & Arbix, Salerno, Zancul et al. \\
\hline Research on design of the smart factory for forging enterprise in the Industry 4.0 environment. & Pei, Tong, He et al. \\
\hline SDMSim: a manufacturing service supply-demand matching simulator under cloud environment. & Tao, Cheng, Cheng et al. \\
\hline $\begin{array}{l}\text { The fourth industrial revolution, agricultural and rural innovation, and implications for public } \\
\text { policy and investments: a case of India. }\end{array}$ & Lele and Goswami \\
\hline The future African workplace: the use of collaborative robots in manufacturing. & Calitz, Poisat and Cullen \\
\hline $\begin{array}{l}\text { The main economic factors of sustainable manufacturing within the industrial policy concept } \\
\text { of Industry 4.0. }\end{array}$ & $\begin{array}{l}\text { Frolov, Kaminchenko, } \\
\text { Kovylkin et al. }\end{array}$ \\
\hline
\end{tabular}




\begin{tabular}{|l|c|}
\hline \multicolumn{2}{|c|}{ PUBLISHED IN 2018 } \\
\hline A review of digital manufacturing-based hybrid additive manufacturing processes. & $\begin{array}{c}\text { Chong, Ramakrishna } \\
\text { and Singh }\end{array}$ \\
\hline China's manufacturing locus in 2025: with a comparison of 'made-in-China 2025' and 'Industry 4.0'. & Li \\
\hline Current problems in China's manufacturing and countermeasures for Industry 4.0. & Feng, Zhang and Zhou \\
\hline Strategic response to Industry 4.0: an empirical investigation on the Chinese automotive industry. & Lin, Lee, Lau et al. \\
\hline Whether medical schools in Russia are ready to develop successfully in the twenty-first century. & $\begin{array}{c}\text { Kiassov, Gumerova, } \\
\text { Abdulkhakov et al. }\end{array}$ \\
\hline
\end{tabular}

Source: Elaborated by the authors.

The articles in Box 1 were published in a 4-year time period, including 2018 to the date collected. One text was published in 2015, 5 articles in 2016, 19 articles published in 2017 (380\% increase compared to 2016 publications) and, at the time of collection, 5 articles were published in 2018 (Graph 3).

\section{Graph 3}

\section{Number of articles published per year related to Industry 4.0 and BRICS found in SCOPUS and Web of Science}

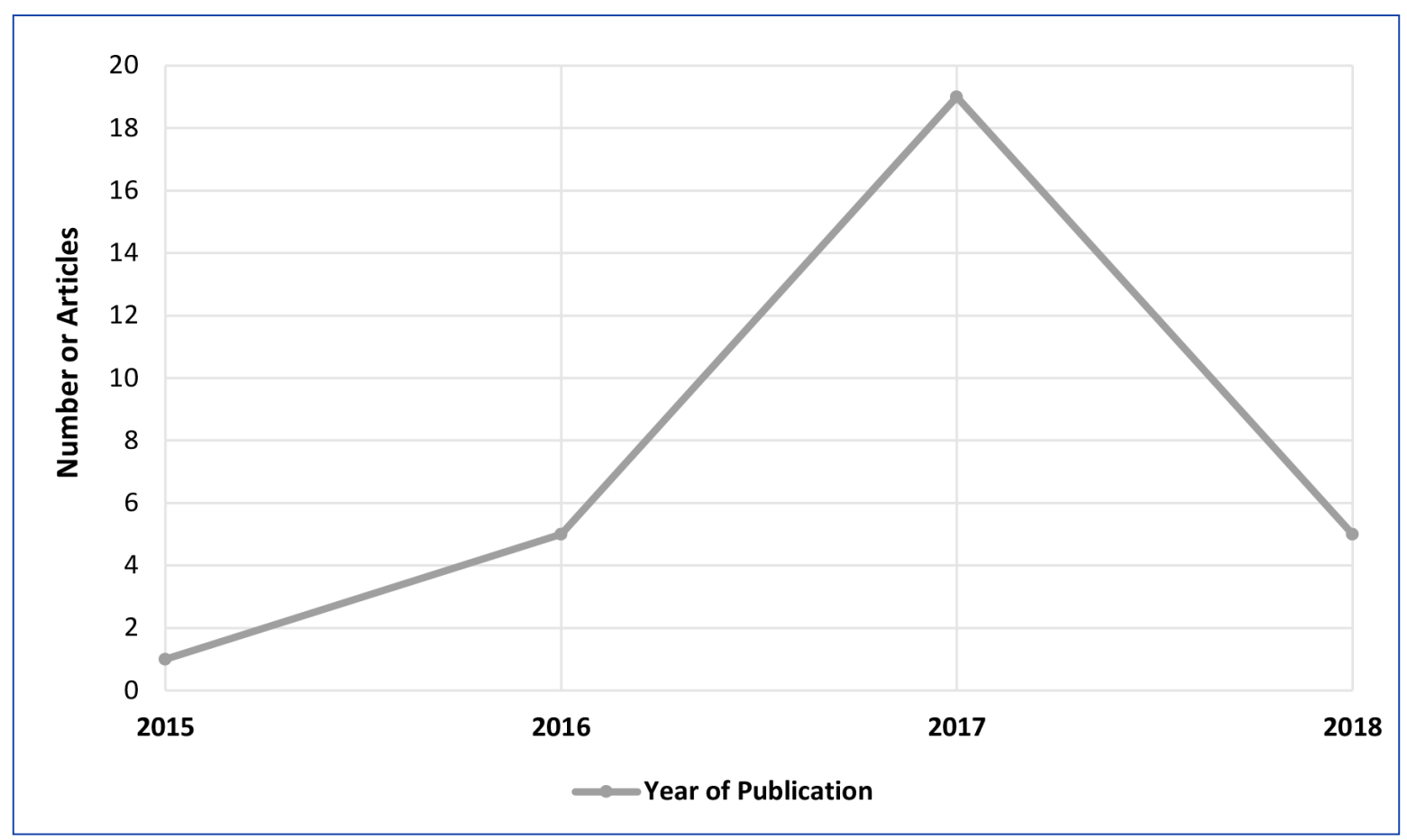

Source: Elaborated by the authors.

Although the time horizon of the research was not restricted, the starting date of the retrieved texts shows a delay of 2 years compared to the text by Kagermann, Wahlster and Helbi (2013). This result also demonstrates the rapid expansion of scientific production on the subject, as observed by Satyro, Sacomano, Silva et al. (2017).

Still on the characterization of the scientific production, it was found that the texts are distributed amongst 26 scientific journals; of these, only 3 have more than 1 article published: IEEE Access has published 3 and Engineering and South African Journal of Industrial Engineering have published 2 each. It was found that most journals analyzed (76.67\%) do not stand out in this regard. Concerning the thematic areas of the journals, 3 emerged: the most published articles were from Engineering, followed by Computer Science, and thirdly Administration, Accounting and Economics (Graph 4). Given that Industry 4.0 involves many sectors of the first 2 areas, this result corroborates what was expected for the fourth IR. 


\section{Graph 4}

Section of the journal where the selected articles were found.

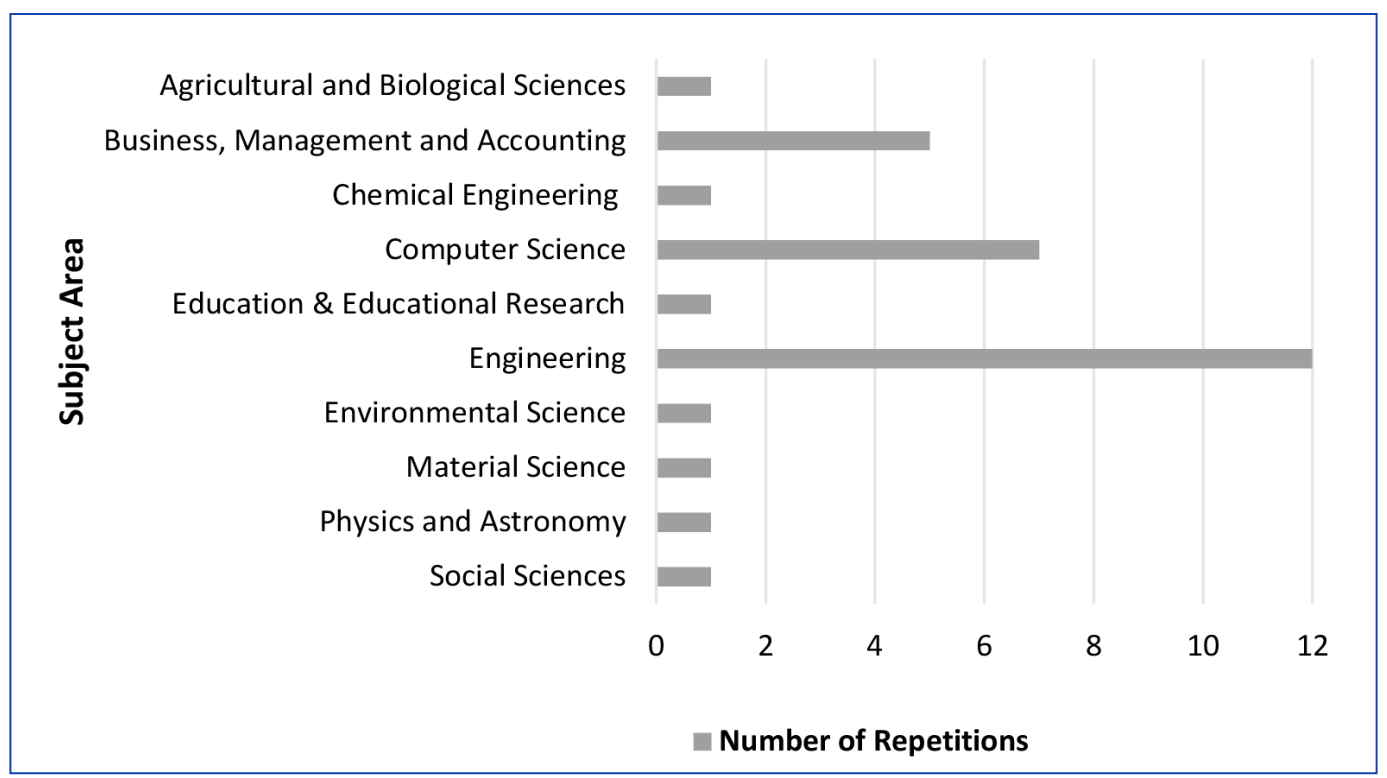

Source: Elaborated by the authors.

The thematic areas of the journals that have given Industry 4.0 visibility reflect what Roblek, Mesko and Krapez (2016) pointed out about the progress towards increasing the productivity of manufacturing operations. For the authors, Industry 4.0 ITs excel in 3 aspects: a) production digitization; b) automation; and c) automatic data exchange in the supply chain (ROBLEK, MESKO and KRAPEZ, 2016), which are in line with the critical success factors identified by Kagermann, Wahlster and Helbi (2013). Direct customer contact with the management of these smart technologies allows for greater involvement with Industry 4.0 and with its perceived value (ROBLEK, MESKO and KRAPEZ, 2016).

As for the occurrence of the terms, the indicator "keywords" was selected. 164 different keywords were found, among which Industry 4.0 stood out with 18 repetitions. Box 2 presents the other keywords that occurred more than once.

Box 2

Most frequently found keywords in the selected articles.

\begin{tabular}{|l|c|}
\hline \multicolumn{1}{|c|}{ Keywords } & $\begin{array}{c}\text { Number of } \\
\text { repetitions }\end{array}$ \\
\hline Internet of Things (IOT) & 7 \\
\hline Cyber-physical systems (CPS) & 6 \\
\hline Integrated manufacturing & 5 \\
\hline Additive manufacturing & 4 \\
\hline $\begin{array}{l}\text { Big Data; Cloud computing; Cloud manufacturing; Digital twin; Emerging economy; } \\
\text { Individualized designing; Industry 3.5; Learning factory; Manufacturing intelligence; } \\
\text { Manufacturing service; Mass individualization; Multi-view synchronization; Patent } \\
\text { analysis; Semi-physical simulation; Smart factory; South Africa. }\end{array}$ & 2 \\
\hline
\end{tabular}

Source: Elaborated by the authors.

Also, in Box 2, it is observed that the keywords that were highlighted represent a set of innovations marked by the advancement of technologies and by the adoption of computers as the main machine. According to Brettel, Friederichsen, Keller et al. (2014) and Hermann, Pentek and Otto (2016), these keywords refer to the intellectual work, to the conception of programs 
that have been the focus of Industry 4.0 ITs, in order to automate the industrial sector as much as possible, in addition to the miniaturization of technologies and the interconnection between everything (and everyone).

It is also noteworthy that $74 \%$ of the keywords are not repeated (Box 2), since the articles cover contexts and research areas with different specialties, such as simulation, climate change and atomic manufacturing. This result is justified by the fact that these very distinct terms relate to sectors, regions analyzed, and specific technology used, showing the multiplicity with which Industry 4.0 is present in the BRICS.

In all, there are 83 authors distributed in the 30 articles analyzed. Regarding scientific productivity, the affiliation of the authors refers to 33 institutions (excluding 2 who claim to be independent researchers and 1 institutional author [Ministry of Industry and Information Technology]), listed in Graph 5, together with the number of authors who are linked to these institutions.

\section{Graph 5}

Institutional affiliation of researchers of the selected articles.

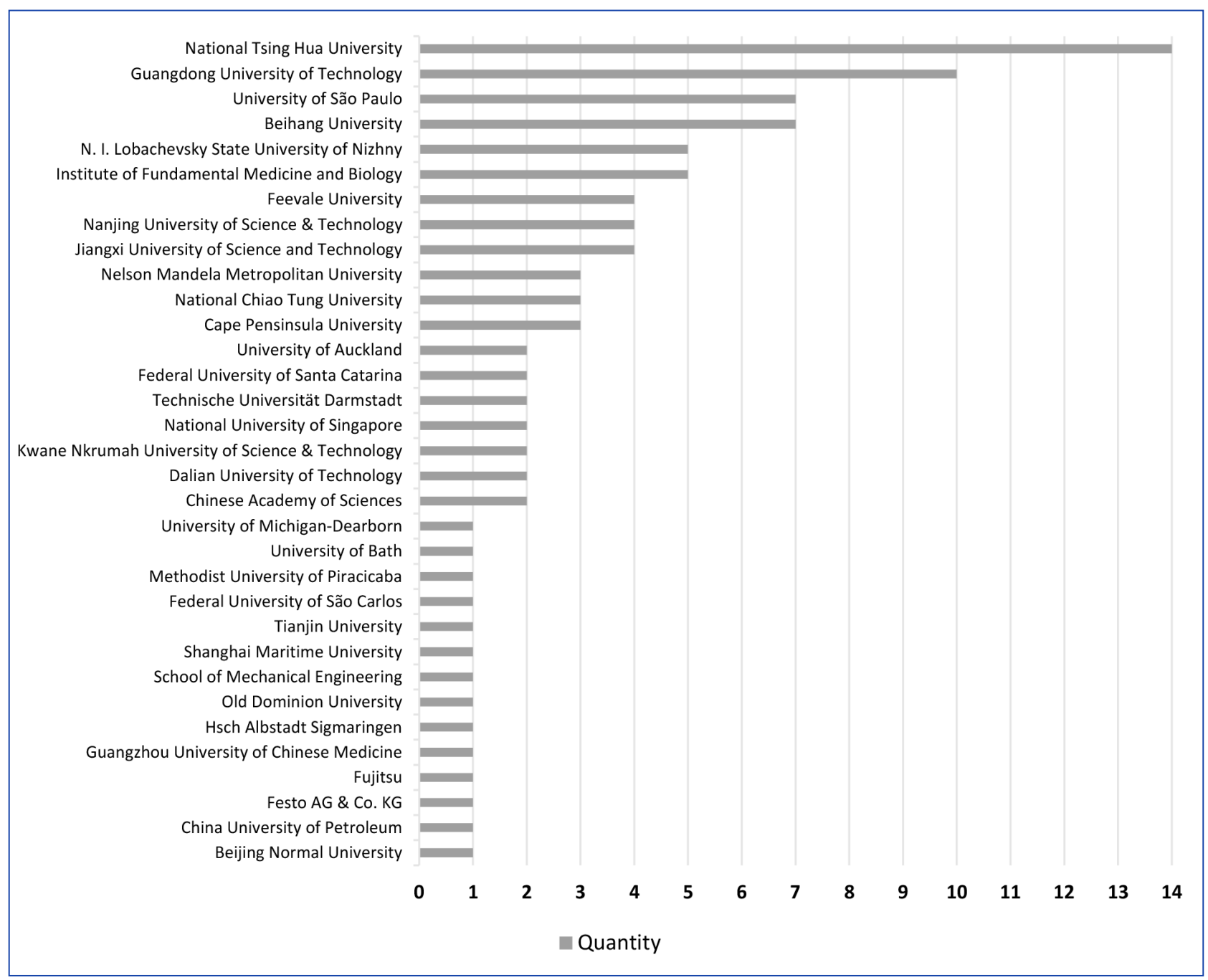

Source: Elaborated by the authors.

The number of articles published by country is presented according to the affiliation informed by the authors when the texts were published (Graph 5). Thus, Graph 6 shows the distribution of articles by country, according to the author's address at the time of publication. 


\section{Graph 6}

Country of the authors of the selected articles.

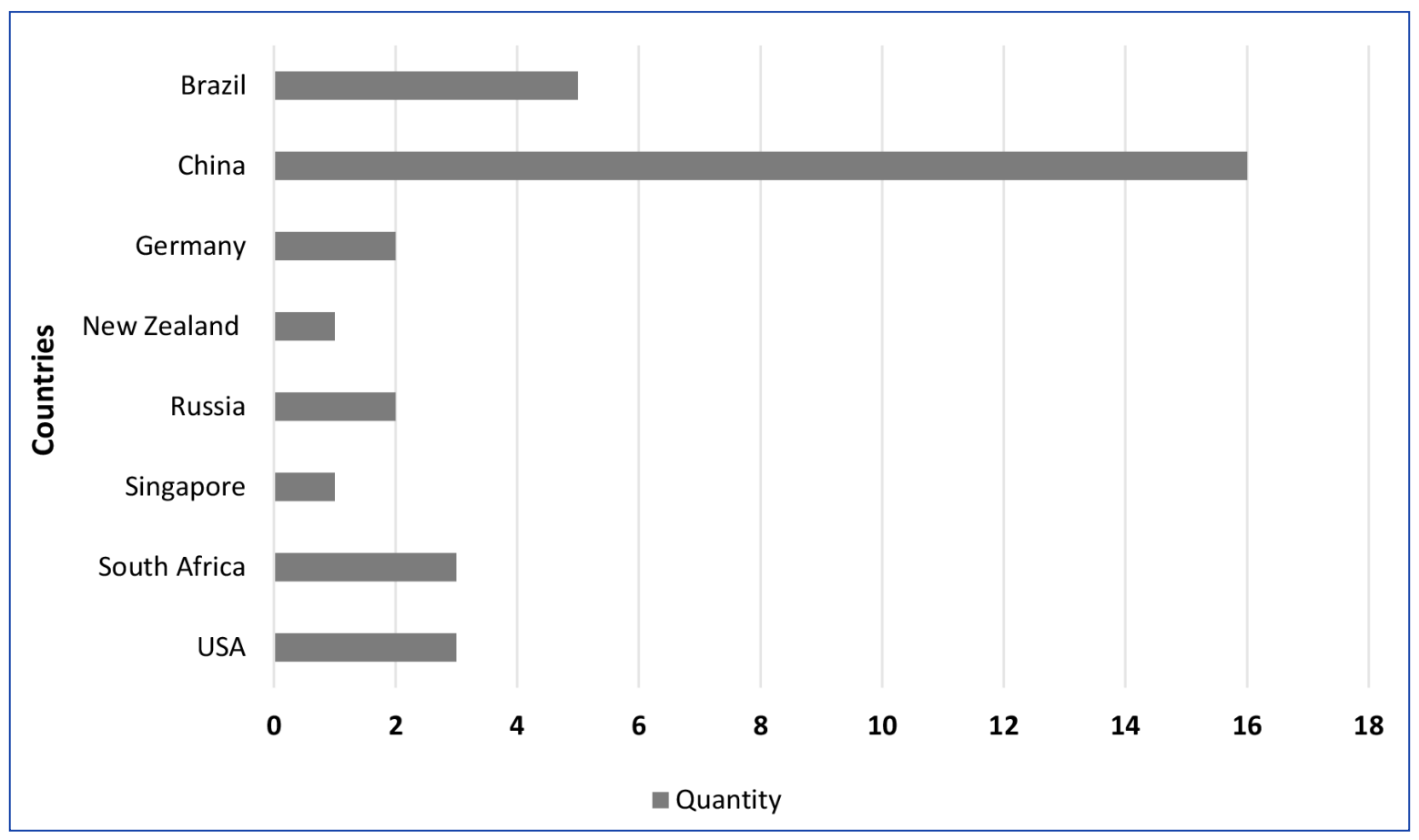

Source: Elaborated by the authors.

In Graph 6, the BRICS country that stands out in article publications is China, followed by Brazil, which is ahead of South Africa (with the same amount as the US) and Russia (which is similar in numbers to Germany). Although articles from India were not found in general, the results converge with other studies that demonstrate the increasing visibility of the bloc's countries in terms of scientific publications, especially China, although the publications with cooperation inter-BRICS are less frequent (FINARDI and BURATTI, 2016; SHASHNOV and KOTSEMIR, 2018). It is important to note that the countries shown on Graph 6 are the union of some technologically advanced countries with others that were used as keywords in the research.

The scientific collaboration was measured by co-authoring and, among the 30 articles, 4 were not written in scientific collaboration (one of them being an institutional author). In its majority, the identified scientific collaboration was performed by diversified studies regarding the number of authors involved: 10 articles were written by 5 authors, 8 texts were the result of the collaboration between 3 authors, 5 articles were written by 2 authors and 3 texts had the collaboration of 4 authors (Graph 7). 
Graph 7

\section{Co-author collaboration among the selected articles}

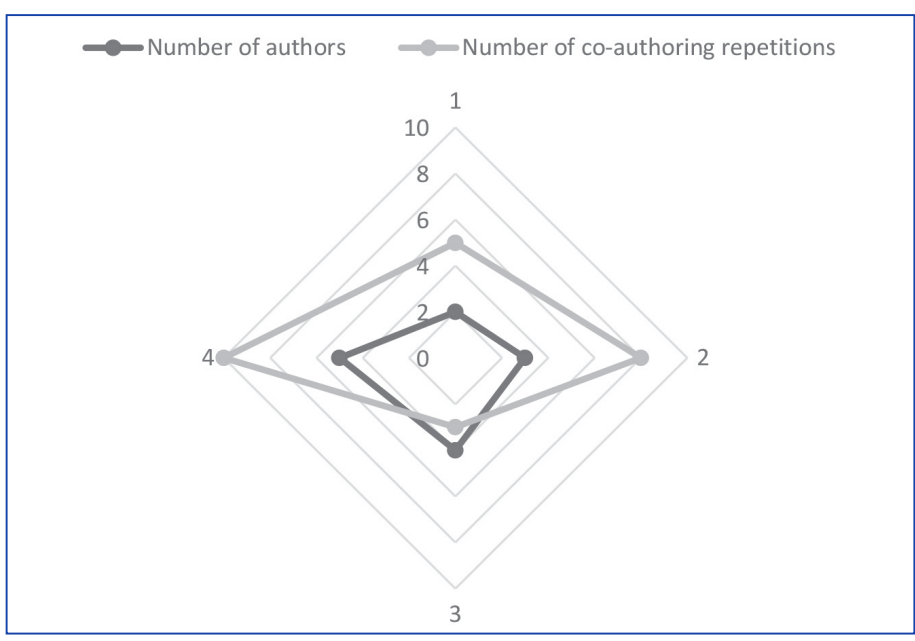

Source: Elaborated by the authors.

Box 3 indicates the most successful authors who participated in more than one article, as well as their institutional affiliation and country. The Chinese prevalence stands out, which includes Taiwan's production in its quantity (due to the current world political position) (ZHAO, WANG, XIAO et al., 2018).

Box 3

Authorship participation, with affiliation, in more than one article

\begin{tabular}{|c|}
\hline PRODUCTION IN THREE ARTICLES \\
\hline Chien, C.-F. (The University of Danang, Taiwan) \\
\hline Tao, F. (Beihang University, China) \\
\hline Plakitkin, Y.A. (ERI RAS, Russia) \\
\hline Plakitkina, L.S. (ERI RAS, Russia) \\
\hline PRODUCTION IN TWO ARTICLES \\
\hline Bester, A. (Cape Peninsula University, South Africa) \\
\hline Cheng, J. (Beihang University, China) \\
\hline Qi, Q. (Beihang University, China) \\
\hline Chen, X. (Guangdong University of Technology, China) \\
\hline Leng, J. (Guangdong University of Technology, China) \\
\hline Liu, Q. (Guangdong University of Technology, China) \\
\hline Zhang, D. (Guangdong University of Technology, China) \\
\hline Zhang, H. (Guangdong University of Technology, China) \\
\hline Sackey, S.M. (Kwame Nkrumah University of Science \& Technology, Ghana) \\
\hline Trappey, C. (National Chiao Tung University, Taiwan) \\
\hline Chuang, A. (National Tsing Hua University, Taiwan) \\
\hline Govindarajan, U. (National Tsing Hua University, Taiwan) \\
\hline Guo, H.-Z. (National Tsing Hua University, Taiwan) \\
\hline Hong, T.-Y. (National Tsing Hua University, Taiwan) \\
\hline Trappey, A. (National Tsing Hua University, Taiwan) \\
\hline Zancul, E. (University of São Paulo, Brazil) \\
\hline Xu, X. (University of Auckland, New Zealand) \\
\hline
\end{tabular}

Source: Elaborated by the authors. 
Regarding the methodological characteristics of the studies, more theoretical essays (18 texts) were found than empirical research (12 articles). One reason for this discrepancy with theoretical and empirical articles may be that loT, while allowing the creation of products and services, is about new business models in almost every industry (ROBLEK, MESKO and KRAPEZ, 2016). Graph 8 illustrates the amount of theoretical and empirical articles per year.

\section{Graph 8}

Distribution of article types over the years: theoretical article $\times$ empirical article

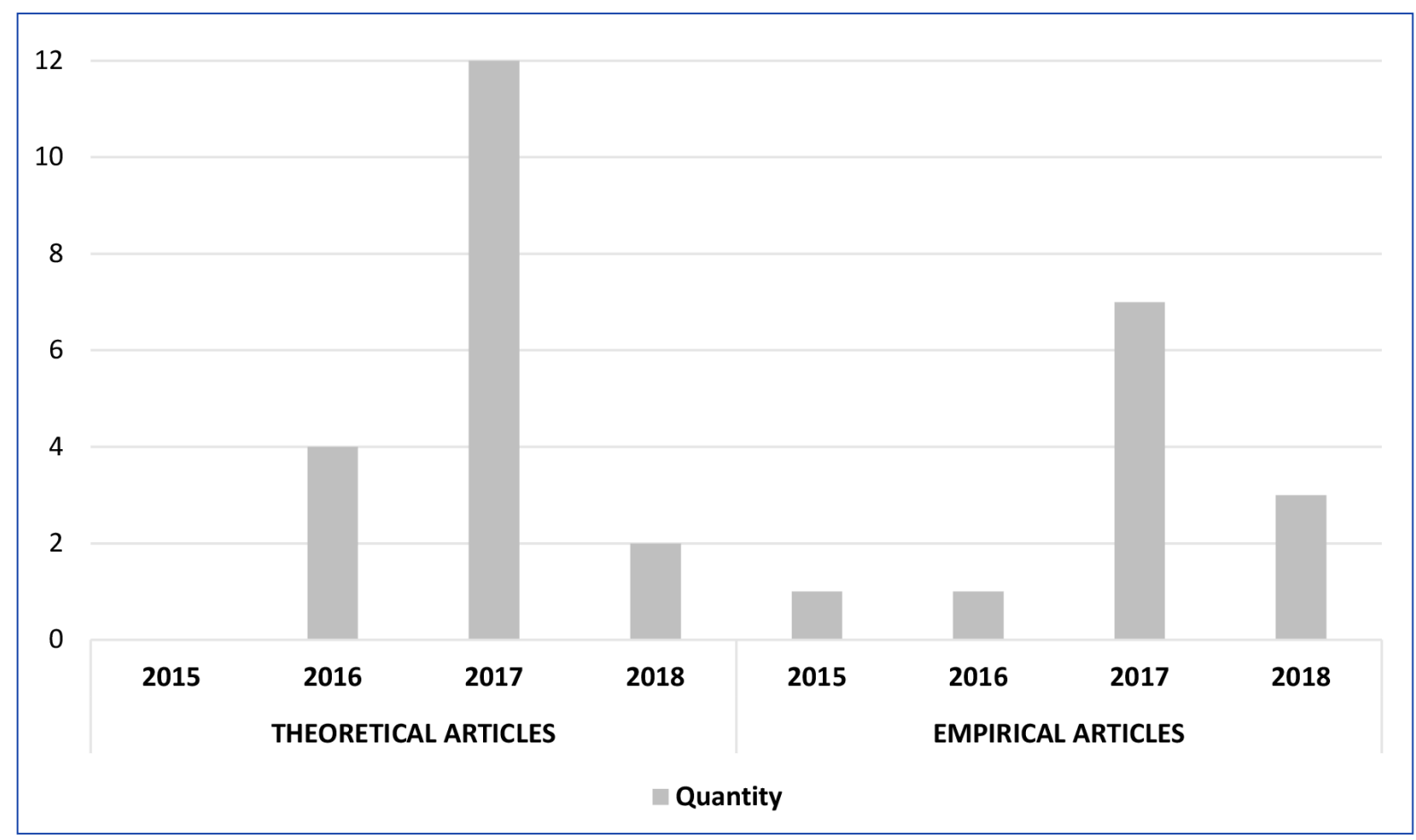

Source: Elaborated by the authors.

Some characteristics can be listed among the 12 empirical studies analyzed:

1. Most are quantitative, using multivariate analysis, structural modeling, descriptive statistics, correlation and linear regression (FENG, ZHANG and ZHOU, 2018; LI, 2018; LIN, LEE, LAU et al., 2018; OLIVEIRA and SOMMER, 2017; TORTORELLA and FETTERMANN, 2017);

2. Other methods related to the area of Exact Sciences were identified, such as genetic algorithm (CHIEN, HONG and GUO, 2017a; ZHANG, LIU, CHEN et al., 2017; WANG, SUN, ZHANG et al., 2016), programming methods (TAO and QI, 2017), and system modeling based on the physics and mathematics of the technological progress (DURÃO, CHRIST and ZANCUL, 2017);

3. The qualitative research used thematic analysis, content analysis and case study (CALITZ, POISAT and CULLEN, 2017; SCHRÖDER, NUNES, VIERO et al., 2015);

4. The collection instruments used, when not mathematical, are questionnaires and interviews; and

5. The most researched sectors are production (CALITZ, POISAT and CULLEN, 2017; LI, 2018; TORTORELLA and FETTERMANN, 2017; WANG, SUN, ZHANG et al., 2016), industrial (LIN, LEE, LAU et al., 2018; CHIEN, HONG and GUO, 2017; ZHANG, LIU, CHEN et al., 2017) and manufacturing (FENG, ZHANG and ZHOU, 2018; SCHRÖDER, NUNES, VIERO et al., 2015). 


\section{Rating Category}

Evaluative categorization was sought in the empirical and theoretical studies, based on 3 indicators: a) employed concept of Industry 4.0; b) conceptual subcategories formulated from this concept; and c) Industry 4.0 interface with catch-up strategies, capacity building for innovation and appropriation of market opportunities. It was observed in the studies that the conceptualization of the term Industry 4.0 was made from 4 distinct strategies, segmented in the perspectives presented in Box 4.

\section{Box 4}

\section{Perspectives and conceptualization strategies employed in the selected articles.}

\begin{tabular}{|c|c|c|}
\hline $\begin{array}{c}\text { Employed } \\
\text { Perspective }\end{array}$ & Industry Conceptualization Strategy 4.0 & Authors \\
\hline Of the Objectives & $\begin{array}{l}\text { Industry } 4.0 \text { is defined by seeking to add value to } \\
\text { manufacturing, the application of / or the potential } \\
\text { exploitation of technologies in manufacturing, and } \\
\text { the interconnection of people and equipment. }\end{array}$ & $\begin{array}{l}\text { Lin, Shyu and Ding (2017); Oliveira and Sommer } \\
\text { (2017); Schröder, Nunes, Viero et al. (2015); } \\
\text { Zhou, Liu and Liang (2016). }\end{array}$ \\
\hline $\begin{array}{l}\text { Of integrating } \\
\text { technologies }\end{array}$ & $\begin{array}{l}\text { Responsible for more than half of the concepts } \\
\text { present in the studies, it defines Industry } 4.0 \text { based } \\
\text { on integrating ITs and is mostly focused on cyber- } \\
\text { physical systems (CPS), cloud computing, IOT and } \\
\text { smart factory. }\end{array}$ & $\begin{array}{l}\text { Chen (2017); Chien, Hong and Guo (2017); } \\
\text { Chong, Ramakrishna and Singh (2018); Tough, } \\
\text { Christ, Zancul et al. (2017); Fang (2016); Feng, } \\
\text { Zhang and Zhou (2018); Lele and Goswami } \\
\text { (2017); Li (2018); Sackey and Bester (2016); } \\
\text { Tortorella and Fettermann (2017); Trappey, } \\
\text { Trappey, Govindarajan et al. (2017); Wang, Sun, } \\
\text { Zhang et al. (2016); Zhang, Liu, Chen et al. (2017). }\end{array}$ \\
\hline Strategical & $\begin{array}{l}\text { The concept merges with the first uses of the term, } \\
\text { in view of the German government's initiative, having } \\
\text { as its characteristic the positioning of the theme as } \\
\text { a national plan focused on real time interconnection } \\
\text { and Germanic industrial competitiveness. }\end{array}$ & $\begin{array}{l}\text { Arbix, Salerno, Zancul et al. (2017); Frolov, } \\
\text { Kaminchenko, Kovylkin et al. (2017); Tao and } \\
\text { Qi (2017); Zhong, Xu, Klotz et al. (2017). }\end{array}$ \\
\hline Historical & $\begin{array}{l}\text { The definition goes back to the historical evolution of } \\
\text { the Industry } 4.0 \text { concept, presenting it as an integral } \\
\text { part of this context (in this sense, the most viewed } \\
\text { term is fourth IR) and comparing it with previous } \\
\text { industrial perspectives, especially Industry 3.0. }\end{array}$ & Chien, Hong and Guo (2017). \\
\hline
\end{tabular}

Source: Elaborated by the authors.

There is a prominence of the integrating technology perspective, which presents the definition of Industry 4.0 based on the conceptualization of some technology connected to it. This position is justified, among other factors, by the fact that Industry 4.0 presents an aggregate of technologies (qualitative and quantitative) not yet experienced in the previous three IRs (ZHOU, LIU and LIANG, 2016; SCHWAB and DAVIS, 2018). Thus, it is possible to conceptualize and research Industry 4.0 from the specific results of its integral parts, due to the complexity of each of the new existing technologies or those that are in the seminal process (SACKEY, BERSTER and ADAMS, 2017).

This complexity is significant to the point that it is possible to visualize and verify diversified actions using the technologies highlighted in the most developed countries (Germany, USA and Japan). However, for countries with industrial infrastructure at an earlier stage, reaching the levels set by the fourth IR may be the possibility of thinking of a transition scenario that is capable of promoting existing manufacturing intelligence (at Industry 3.0) and maintaining satisfactory levels of competitiveness, a scenario in which an Industry 3.5 can be established (CHIEN, HONG and GUO, 2017).

It reinforces the argument presented on the amount of technologies instilled in the concept or detailed explanation of Industry 4.0 found in the 30 articles studied. In 79 citations there were 22 distinct typologies of technologies found (Graph 9), with 
4 of them accounting for more than half of citations: Internet of Things (IoT) (15), Cyber-physical Systems (CPS) (14), Cloud Computing (9) and Big Data (7).

\section{Graph 9}

Technologies present in the conceptualization and explanation of Industry 4.0

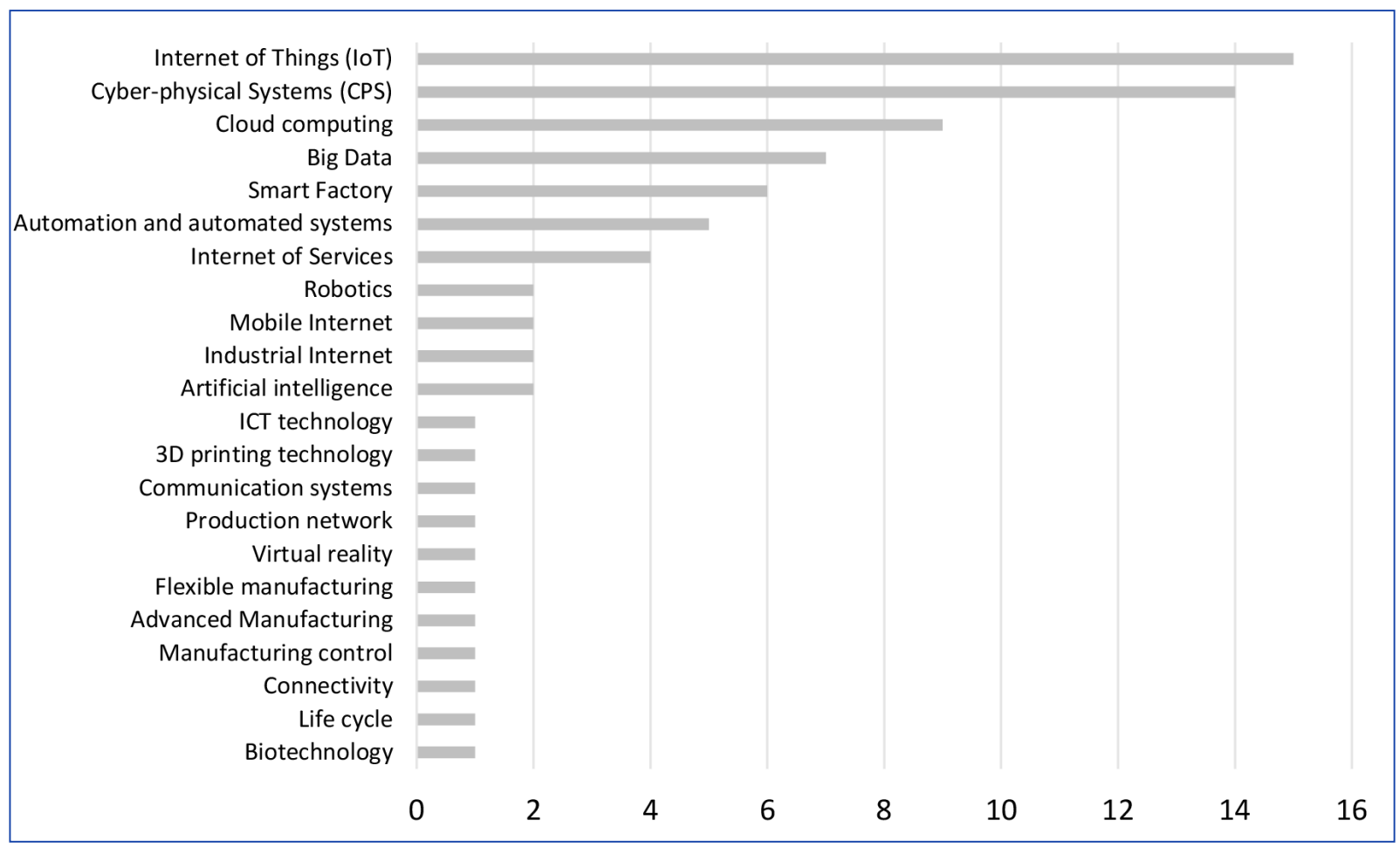

Source: Elaborated by the authors.

Graph 9 presents the technologies found in the articles about the context of Industry 4.0, revealing the diversity of technologies that can be linked to the theme. It is noteworthy that the perspective of conceptualization based on Industry 4.0 technologies was more frequent compared to the other conceptualization categories. It is evident that some empirical studies focused on the most apparent technologies in the established analysis, especially in the scrutiny of aspects related to the organization, such as productivity and performance (CALITZ, POISAT and CULLEN, 2017; LIN et al., 2018), or even experimentation of mathematical instruments (CHIEN, HONG and GUO, 2017, ZHANG, LIU, CHEN et al., 2017).

\section{CONCLUSION}

It is necessary to comment that the performed discussion does not exhaust the literature produced so far on the subject and shows, on the tracking performed, a current portrait of publications, references and citations of the intellectual growth of Industry 4.0, in the context of the BRICS. What represents the Industry 4.0 phenomenon are the expressions that are associated with it, as they show which parts of the economy, or the environment, the technologies of a given context are expanding (ROBLEK, MESKO and KRAPEZ; 2016). This study identified the main descriptive characteristics of the theme and of the researched field and revealed, through evaluative analysis, the concepts employed by the authors and their associated relationships, contained in a relevant literature regarding scientific production.

This study indicated the increase in research on Industry 4.0 in S\&T and what has been reflected in the theme Industry 4.0 in the BRICS, but also the need for effective strengthening of the political cooperation of these countries in the aspects related to the subject, as foreseen in the agreements and work plans established in recent years (e.g. BRICS STI, 2015, 2017). Therefore, 
as advocated by Wong and Wang (2015) and Zhao, Wang, Xiao et al. (2018), from the joint establishment of priority S\&T areas, involving international cooperation of interest to the bloc (intra and extra-BRICS), to the survey of socio-economic requirements and possibilities for S\&T development in each country, it is all relevant.

Among the limitations of this article, it is observed that the criteria for text selection left out published papers that have been presented in congresses, as well as books and scientific articles not classified by the Web of Science and SCOPUS databases. Despite the significant representativeness, if the choice not to search local databases and specific areas, on the one hand, privileged interdisciplinary and international studies, on the other, brought as a limitation the predominance of English language studies and researches inserted in the disciplines of the Exact Sciences field, to the detriment of other areas and national indexes, as pointed out by Mongeon and Paul-Hus (2016).

Nevertheless, this result makes sense when considering that the keywords used were written in English and that Industry 4.0 is based on advances that come mainly from Engineering and Computer Science. It is suggested that as prospects for future studies to add as a search term each of the ITs pointed out by Rüssmann, Lorenz, Gerbert et al. (2015), in each of the countries that make up the BRICS, nominally, in addition to expanding the searched databases, including national / local databases. For further research on the relationship between the productive and academic sectors, it is suggested to add to the analysis the patent bases in each of the BRICS.

As a positive aspect, it is considered that this article may help future works to understand how this new concept has been introduced together with the adoption of new technologies connected to it, as well as the opinions of researchers on the subject in different fields of study. In addition, the information presented in this article are useful for researchers who intend to know in what vectors the industry is positioning itself in recent years in the emerging countries, which can guide various policies and decisions, especially those related to R\&D. Although this study is not based on a deep survey, it presents a range of references on the subject, facilitating future researches that will reevaluate this early period of Industry 4.0 in the world. 


\section{REFERENCES}

ABRAMOVITZ, M. Catching up, forging ahead, and falling behind. Journal of Economic History, v. 46, n. 2, p. 386-406, 1986.

ARBIX, G. et al. O Brasil e a nova onda de manufatura avançada: o que aprender com Alemanha, China e Estados Unidos. Novos estudos CEBRAP, v. 36, n. 3, p. 29-49, 2017.

BERNARDES, A. T. et al. Modeling economic growth fuelled by science and technology. Belo Horizonte: UFMG/Cedeplar, 2006.

BRETTEL, M. et al. How virtualization, decentralization and network building change the manufacturing landscape: an Industry 4.0 perspective. International Journal of Mechanical, Aerospace, Industrial and Mechatronics Engineering, v. 8, n. 1, p. 37-44, 2014.

BRICS SCIENCE, TECHNOLOGY AND INNOVATION MINISTERIAL MEETING - BRICS STI. Memorandum of understanding on cooperation in science, technology and innovation. Brasilia, DF: BRICS, 2015.

BRICS SCIENCE, TECHNOLOGY AND INNOVATION MINISTERIAL MEETING - BRICS STI. Leading through innovation \& deepening cooperation. Hangzhou: BRICS, 2017.

CALITZ, A. P., POISAT, P.; CULLEN, M. The future African workplace: The use of collaborative robots in manufacturing. SA Journal of Human Resource Management, v. 15, n. 2, p. 1-11, 2017.

CASTELLS, M. A era da informação: economia, sociedade e cultura. A sociedade em rede. Lisboa: Fundação Calouste Gulbenkian, 2002. v. 1.

CHEN, Y. Integrated and intelligent manufacturing: perspectives and enablers. Engineering, v. 3, n. 5, p. 588-595, 2017.

CHIEN, C.-F.; HONG, T.; GUO, H.-Z. A conceptual framework for "Industry 3.5" to empower intelligent manufacturing and case studies. Procedia Manufacturing, v. 11, p. 2009-2017, 2017a.

CHIEN, C.-F.; HONG, T.; GUO, H.-Z. An empirical study for smart production for TFT-LCD to empower Industry 3.5. Journal of the Chinese Institute of Engineers, v. 40, n. 7, p. 552-561, 2017b.

CHONG, L.; RAMAKRISHNA, S.; SINGH, S. A review of digital manufacturing-based hybrid additive manufacturing processes. The International Journal of Advanced Manufacturing Technology, v. 95 , n. $5-8$, p. $2281-2300,2018$.

COOPER, A. F. The BRICS: a very short introduction. Oxford: Oxford University Press, 2016.

COSTA, K. F.; MENEZES, H.; FRANZONI, M. Inovação desenvolvimento: a importância das relações internacionais. Monções: Revista de Relações Internacionais da UFGD, v. 5, n. 9, p. 152-190, 2016.

COSTIN, C.; WOOD-JÚNIOR, T. Criando alianças estratégicas entre universidades e empresas: o caso Uniemp. Revista de Administração (São Paulo), v. 29, n. 2, p. 95-104, 1994.

DOMINICI, G. et al. Click and drive: consumer attitude to product development. Towards future transformations of driving experience. Business Process Management Journal, v. 22, n. 2, p. 420-434, 2016.

DRATH, R.; HORCH, A. Industrie 4.0- hit or hype? IEEE Industrial Electronics Magazine, v. 8, n. 2, p. 56-58, 2014.
DURÃO, L. F. C. S. et al. Additive manufacturing scenarios for distributed production of spare parts. The International Journal of Advanced Manufacturing Technology, v. 93, n. 1-4, p. 869-880, 2017.

FANG, F. Z. Atomic and close-to-atomic scale manufacturing: a trend in manufacturing development. Frontiers of Mechanical Engineering, v. 11, n. 4, p. 325-327, 2016.

FENG, L.; ZHANG, X.; ZHOU, K. Current problems in China's manufacturing and countermeasures for industry 4.0. EURASIP Journal on Wireless Communications and Networking, v. 2018 n. 90, p. 1-6, 2018.

FINARDI, U.; BURATTI, A. Scientific collaboration framework of BRICS countries: an analysis of international coauthorship. Scientometrics, v. 109, n. 1, p. 433-446, 2016.

FROLOV, V. G. et al. The main economic factors of sustainable manufacturing within the industrial policy concept of industry 4.0. Academy of Strategic Management Journal, v. 16, n. 2, 2017.

GOMES, R.; STRACHMAN, E. O papel das multinacionais no desenvolvimento tecnológico do Brasil: políticas industriais como indutoras de catch up tecnológico. São Paulo em Perspectiva, v. 19, n. 2, p. 41-50, 2005.

GUERRA, S. M. G.; FANTINELLI, J. T. A aproximação entre tecnologia e economia: os emergentes papéis da energia. Revista de Estudos Sociais, v. 3, n. 5, p. 33-58, 2001.

HERMANN, M.; PENTEK, T.; OTTO, B. Design principles for Industrie 4.0 scenarios. In: HAWAII INTERNATIONAL CONFERENCE ON SYSTEM SCIENCES, 49., 2016, Koloa. Proceedings... Koloa, HI: [s.n.], 2016. p. $3928-3935$

HOFFMAN, D. L.; HOLBROOK, M. B. The intellectual structure of consumer research: a bibliometric study of author cocitations in the first 15 years of the Journal of Consumer Research. Journal of Consumer Research, v. 19, n. 4, p. 505-517, 1993.

HUBERMAN, L. História da riqueza do homem. 21. ed. Rio de Janeiro: LTC, 2008.

IPIRANGA, A. S. R. et al. Estratégias de inovação de catching-up: as ligações de aprendizagem entre um instituto de $P \& D$ e pequenas empresas. Revista de Administração Pública, Rio de Janeiro, v. 46, n. 3, p. 677-700, 2012

JADEJA, Y.; MODI, K. Cloud computing: concepts, architecture and challenges. In: INTERNATIONAL CONFERENCE ON IEEE, 2012, Kumaracoil, India. Proceedings... Kumaracoil: IEEE, 2012. p. 877-880.

KAGERMANN, H.; WAHLSTER, W.; HELBI, J. Recommendations for implementing the strategic initiative INDUSTRIE 4.0. Frankfurt: National Academy of Science and Engineering/Federal Ministry of Educations and Research, 2013.

KIASSOV, A. et al. Whether medical schools in Russia are ready to develop successfully in the twenty-first century. BioNanoScience, v. 8, n. 1, p. 467-472, 2018.

KINGAH, S.; QUILICONI, C. Introduction: The BRICS in Global and Regional Governance. In: KINGAH, S.; QUILICONI, C. (Ed.). Global and regional leadership of BRICS countries. New York: Springer, 2016. p. 1-12. 
KON, A. Nova economia política dos serviços. São Paulo: Perspectiva/ CNPq, 2015.

LELE, U.; GOSWAMI, S. The fourth industrial revolution, agricultural and rural innovation, and implications for public policy and investments: a case of India. Agricultural Economics, v. 48, n. S1, p. 87-100, 2017.

LI, L. China's manufacturing locus in 2025: with a comparison of "Made-in-China 2025" and "Industry 4.0." Technological Forecasting and Social Change, v. 135, p. 66-74, out. 2018.

LIAO, Y. et al. The impact of the fourth industrial revolution: a crosscountry/region comparison. Production, v. 28, e20180061, p. 1-18, 2017.

LIN, D. et al. Strategic response to Industry 4.0: an empirical investigation on the chinese automotive industry. Industrial Management \& Data Systems, v. 118, n. 3, p. 589-605, 2018.

LIN, K. C.; SHYU, J. Z.; DING, K. A cross-strait comparison of innovation policy under Industry 4.0 and Sustainability Development Transition. Sustainability, v. 9, n. 5, p. 1-17, 2017.

LUÍS, A. L. Rússia: economia emergente ou re-emergente? R-LEGO, n. 2, p. 97-123, 2016.

MANSFIELD, E. D. Rising powers in the Global Economy: issues and questions. International Studies Review, v. 16, n. 3, p. 437-442, 2014.

MARICATO, J. M.; NORONHA, D. P. Indicadores bibliométricos e cientométricos em CT\&I: apontamentos históricos, metodológicos e tendências de aplicação. In: HAYASHI, M. C. P. I.; LETA, J. (Org.). Bibliometria e cientometria: reflexões teóricas e interfaces. São Carlos, SP: Pedro \& João, 2012. p. 21-41.

MIYAZAKI, K.; ISLAM, N. Nanotechnology systems of innovation: an analysis of industry and academia research activities. Technovation, v. 27, n. 11, p. 661-675, 2007.

MONGEON, P.; PAUL-HUS, A. The journal coverage of Web of Science and Scopus: a comparative analysis. Scientometrics, v. 106, n. 1, p. 213-228, 2016

OLIVEIRA, P. S.; SOMMER, L. Globalization and digitalization as challenges for a professional career in manufacturing industries: differences in awareness and knowledge of students from Brazil and Germany. Education Sciences, v. 7, n. 2, p. 55-67, 2017.

ORGANISATION FOR ECONOMIC CO-OPERATION AND DEVELOPMENT - OECD. Main Science and Technology Indicators. Paris: OECD Publishing, 2019. v. 2018, n. 2.

PALATTELLA, M. R. et al. Internet of things in the $5 \mathrm{G}$ era: enablers, architecture, and business models. IEEE Journal on Selected Areas in Communications, v. 34, n. 3, p. 510-527, 2016.

$\mathrm{PEI}, \mathrm{F}$. et al. Research on design of the smart factory for forging enterprise in the Industry 4.0 environment. Mechanika, v. 23, n. 1, p. 146-152, 2017

PITASSI, C. Inovação aberta nas estratégias competitivas das empresas brasileiras. REBRAE, v. 7, n. 1, p. 18-36, 2014.

QIN, J.; LIU, Y.; GROSVENOR, R. A categorical framework of manufacturing for Industry 4.0 and beyond. Procedia CIRP, v. 52, p. 173-178, 2016.
ROBLEK, V.; MESKO, M.; KRAPEZ, A. A complex view of Industry 4.0. Sage Open, v. 6, n. 2, p. 1-11, 2016.

ROEMER, R.; BORCHARDT, R. Understanding bibliometrics. In: ROEMER, R.; BORCHARDT, R. (Ed.). Meaningful metrics: a 21st century librarian's guide to bibliometrics, altmetrics, and research impact. Chicago, IL: Association of College and Research Libraries, 2015. p. 27-70.

RÜSSMANN, M. et al. Industry 4.0: the future of productivity and growth in manufacturing industries. Boston: BCG, 2015.

SANTOS, R. N.; KOBASHI, N. Y. Bibliometria, cientometria, infometria: conceitos e aplicações. Pesq. Bras. Ci. Inf., v. 2, n. 1, p. 155-172, 2009.

SACKEY, S. M.; BESTER, A. Industrial engineering curriculum in Industry 4.0 in a South African context. The South African Journal of Industrial Engineering, v. 27, n. 4, p. 101-114, 2016.

SACKEY, S. M.; BESTER, A; ADAMS, D. Industry 4.0 learning factory didactic design parameters for industrial engineering education in South Africa. The South African Journal of Industrial Engineering, v. 28 , n. 1 , p. $114-124,2017$

SARTI, F.; HIRATUKA, C. Desempenho recente da indústria brasileira no contexto de mudanças estruturais domésticas e globais. Campinas: Unicamp, 2017. (Texto para Discussão Unicamp, n. 290). Available at: <http://www.eco.unicamp.br/docprod/downarq.php?id=3510\&tp=a>. Accessed on: Nov. 11, 2019.

SATYRO, W. C. et al. Industry 4.0: Evolution of the Research at the APMS Conference. In: LÖDDING, H. et al. (Eds.). Advances in Production Management Systems. The Path to Intelligent, Collaborative and Sustainable Manufacturing. Cham: Springer, 2017. p. 39-47. (IFIP Advances in Information and Communication Technology, v. 513).

SCHRÖDER, R. et al. Analysis of implementation of an automated process in a footwear company: a case study by the optic of the Hyundai production system and industry 4.0. Espacios, v. 36, n. 18, p. 19, 2015.

SCHWAB, K. The fourth industrial revolution. Geneva: World Economic Forum, 2016.

SCHWAB, K.; DAVIS, N. Shaping the future of the fourth industrial revolution. New York: Currency, 2018.

SHASHNOV, S.; KOTSEMIR, M. Research landscape of the BRICS countries: current trends in research output, thematic structures of publications, and the relative influence of partners. Scientometrics, v. 117, n. 2, p. 1115-1155, 2018.

SILVA, M. R.; HAYASHI, C. R. M.; HAYASHI, M. C. B. I. Análise bibliométrica e cientométrica: desafios para especialistas que atuam no campo. InCID: Revista de Ciência da Informação e Documentação, v. 2, n. 1, p. 110-129, 2011.

SILVERMAN, D. Interpretação de dados qualitativos: métodos para análise de entrevistas, textos e interações. Porto Alegre: Artmed, 2009.

SODOLOV, A. et al. S\&T priorities for BRICS countries: in search of a win-win strategy. In: ZHAO, X. et al. (Ed.). BRICS Innovative Competitiveness Report 2017. Singapore: Springer, 2018. p. 31-68.

STOCK, T.; SELIGER, G. Opportunities of sustainable manufacturing in Industry 4.0. Procedia CIRP, v. 40, p. 536-541, 2016.

TADEU, H. F. B.; SANTOS, E. S. O que seria a Indústria 4.0? Rio de Janeiro: FDC, 2016. Available at: <http://acervo.ci.fdc.org.br/AcervoDigital/ 
Relat\%C3\%B3rios\%20de\%20Pesquisa/Relat\%C3\%B3rios\%20de\%20 Pesquisa\%202016/O\%20que\%20seria\%20a\%20ind\%C3\%BAstria\%20 4.0-\%20fev\%202016.pdf>. Accessed on: Feb. 27, 2018.

TAO, F. et al. SDMSim: a manufacturing service supply-demand matching simulator under cloud environment. Robotics and ComputerIntegrated Manufacturing, v. 45, p. 34-46, June 2017.

TAO, F.; QI, Q. New IT driven service-oriented smart manufacturing: framework and characteristics. IEEE Transactions on Systems, Man, and Cybernetics: Systems, v. 49, n. 1, p. 81-91, 2017.

TAO, F.; ZHANG, M. Digital twin shop-floor: a new shop-floor paradigm towards smart Manufacturing. IEEE Access, v. 5, p. 20418-20427, 2017.

THE WORLD BANK. Multipolarity: the new global economy. Washington, DC: The World Bank, 2011.

TORTORELLA, G. L.; FETTERMANN, D. Implementation of Industry 4.0 and lean production in brazilian manufacturing companies. International Journal of Production Research, v. 56, n. 8, p. 2975-2987, 2017.

TRAPPEY, A. J. C. et al. A review of technology standards and patent portfolios for enabling cyber-physical Systems in advanced manufacturing. IEEE Access, v. 4, p. 7356-7382, 2016.

TRAPPEY, A. J. C. et al. A review of essential standards and patent landscapes for the Internet of Things: a key enabler for Industry 4.0. Advanced Engineering Informatics, v. 33, p. 208-229, 2017.

UNITED NATIONS EDUCATIONAL, SCIENTIFIC AND CULTURAL ORGANIZATION - UNESCO. Global Investments in R\&D. Paris: UNESCO, 2018a. (Fact Sheet, n. 50).
UNITED NATIONS EDUCATIONAL, SCIENTIFIC AND CULTURAL ORGANIZATION - UNESCO. Human Resources in R\&D. Paris: UNESCO, 2018b. (Fact Sheet, n. 49).

WANG, J. et al. Large-scale online multitask learning and decision making for flexible manufacturing. IEEE Transactions on Industrial Informatics, v. 12, n. 6, p. 2139-2147, 2016.

WONG, C.-Y.; WANG, L. Trajectories of science and technology and their co-evolution in BRICS: insights from publication and patent analysis. Journal of Informetrics, v. 9, p. 90-101, 2015.

YIN, S.; KAYNAK, O. Big data for modern industry: challenges and trends (point of view). Proceedings of the IEEE, v. 2, p. 143146, 2015.

ZHANG, $H$. et al. A digital twin-based approach for designing and multi-objective optimization of hollow glass production line. IEEE Access, v. 5, p. 26901-26911, 2017.

ZHAO, X. et al. Forecast and evaluation of innovation capabilities and review of STI cooperation of BRICS. In: ZHAO, X. et al. (Ed.). BRICS Innovative Competitiveness Report 2017. Singapore: Springer, 2018. p. 3-30.

ZHONG, R. Y. et al. Intelligent manufacturing in the context of Industry 4.0: a review. Engineering, v. 3, n. 5, p. 616-630, 2017.

ZHOU, K.; LIU, T.; LIANG, L. From cyber-physical systems to Industry 4.0: make future manufacturing become possible. International Journal of Manufacturing Research, v. 11, n. 2, p. 167-188, 2016. 
PhD in Business Administration from the University of Brasilia (UnB); Associate Professor at the Federal University of Pernambuco (UFPE), Caruaru- PE, Brazil. E-mail: suelimenelau@gmail.com

Francisco Guilherme Lima Macedo

ORCID: https://orcid.org/0000-0002-5785-3026

PhD in Business Administration from the University of Brasilia (UnB); Assistant Professor at the IESB University Center, Brasília - DF, Brazil. E-mail: guilhermelima03@gmail.com

Patrícia Lacerda de Carvalho

ORCID: https://orcid.org/0000-0001-7007-0133

Doctoral student in Business Administration from the Federal University of Paraíba (UFPB), João Pessoa- PB, Brazil. E-mail: patricialacerdac@gmail.com

Thiago Gomes Nascimento

ORCID: https://orcid.org/0000-0002-2432-3117

$\mathrm{PhD}$ in Management Sciences from Aix-Marseille Université (AMU, France); PhD in Business Administration from the University of Brasilia (UnB); Professor at the IESB University Center, Brasília- DF, Brazil. E-mail: tgn.1980@gmail.com

Antônio Deusany de Carvalho Júnior

ORCID: https://orcid.org/000-0003-1960-7841

PhD in Computer Science from the University of São Paulo (USP); Collaborating Professor at the University of São Paulo (USP), São Paulo- SP, Brazil. E-mail:dj@ime.usp.br 